\title{
Efficacy of an Instructional Intervention Program on Obstetric Nurses' Information and Perceptions Relating To Transcutaneous Electrical Nerve Stimulation throughout Labor
}

\author{
Aida Abd El-Razek \\ Associate Professor of Maternal \& Child Health Nursing at Philadelphia University
}

\begin{abstract}
Objective: To evaluate the instructional intervention program on obstetrics nurses information and perceptions relating to transcutaneous electrical nerve stimulation throughout labor.

Design: A quasi-experimental design was utilized

Setting: Prince Hussein Bin Abdullah hospital, Jordan

Participants: Sixty-five obstetric nurses $(O B)$, from the labor unit within the OB department

Methods: Participants were interviewed through structured interviews, including OB nurses' information, and Nurses perception tools relating to transcutaneous electrical nerve stimulation it were used to assess nurses' perception relating to transcutaneous electrical nerve stimulation their perceptions of, transcutaneous electrical nerve stimulation.

Results: The study discovered that $93.8 \%$ of nurses had poor information of transcutaneous electrical nerve stimulation prior to the intervention program. However, $94.6 \%$ of them recorded good information immediately after their intervention program and $85.5 \%$ still had good information about transcutaneous electrical nerve stimulation 3 months later. Before intervention only $1.9 \%$ of the nurses had positive perceptions regarding transcutaneous electrical nerve stimulation.

Conclusion: Instructional intervention program provided was effective and significantly improved nurses' information \& perceptions relating to transcutaneous electrical nerve stimulation.

The study recommended that adequately planned in-service coaching programs to develop nurses' information, and perceptions regarding transcutaneous electrical nerve stimulation, ought to be provided. Such initiatives could sensitize such nurses to newly developed ideas in the vital field of care throughout labor.
\end{abstract}

Keywords: transcutaneous electrical nerve stimulation, instructional intervention program

\section{Introduction}

Labor pain from uterine contraction is a physiological process; a complex, subjective and multidimensional response to the sensory stimuli that are primarily generated by uterine contraction ${ }^{1}$. Pain management plays a very important role throughout labor, as its effectiveness contributes to the physical well-being of each mother and fetus.

Drugs, epidural analgesia, local blockades, psycho-prophylactic strategies and TENS are examples of the alternatives for reducing pain throughout a woman's labor. ${ }^{1,2}$ TENS is a pain relief method where a special device transmits low-tension electrical impulses through electrodes onto the skin of the area of the body that is in pain. TENS is an efficient method for relieving acute and chronic pain caused by surgery, childbirth, tension headaches, injuries, arthritis, tendonitis, bursitis, chronic wounds, cancer and alternative paincausing issues. Furthermore, as TENS is helpful to assist manage nerve (neuropathic) pain, an issue that is often accompanied with or manifested by tingling symptoms or a burning sensation, some practitioners believe that TENS stimulates the assembly of endorphins; the latter being acknowledged as the body's natural painkillers $3,4,5$ TENS is a safe, simple-to-use, drug free method for managing pain. An extremely low level electrical current is applied to areas of the body via soft gel pads that are in contact with the skin; TENS is therefore a 'transcutaneous' model operating "through the skin". 6,7 The low level electrical current stimulates nerves within the body that facilitate a reduction in perceived levels of pain ${ }^{8}$ Pain throughout birth is an arduous challenge for a woman to manage, particularly the prima gravida.

Almost all women experience severe pain throughout labor; therefore, those women need qualified nurses who will facilitate the birthing process by providing support and care; in particular management of the woman's pain. Non-medicinal measures of pain-relief are shown to be safe, cheap and simple to apply. TENS could be a 'natural' and relatively easy way of relieving labor pain; it can be simply applied by the nurse without involving any medical prescription. ${ }^{6,8,9}$

Recent advances in science have incontestable evidence that TENS is a save source of pain relief, and therefore a should be valuable resource within the clinical field throughout labor. ${ }^{9,10}$ 
In spite of the numerous advantages of TENS, this method was not considered for inclusion within the nursing care provided for the Jordanian women throughout their labor. The researchers found that the obstetrics nurses lacked information regarding the advantages and uses of TENS, as well as exhibiting a range of negative perceptions concerning the subject of TENS. Hence, it is imperative to lift obstetric nurses' levels of knowledge regarding recent problems relating to TENS. This study has been conducted to boost obstetrics nurses' levels of TENS related information, as well as to move their perceptions of TENS in a positive direction. This study is the first in Jordan to focus on midwifery information and nurses' perceptions concerning both the concept and practical application of TENS as a means of pain management during labor.

\subsection{Study aims}

\section{Study Design, Setting, Subjects And Methods}

Aim of the study: to evaluate an instructional intervention program designed to provide obstetrics nurses with information, as well as change their perceptions relating to TENS throughout labor, in a positive direction.

\subsection{Hypotheses}

1) Obstetrics nurses who received an instructional intervention program would have improved levels of information and understanding concerning TENS, compared to their levels before the program.

2) Obstetrics nurses who received an instructional intervention program would have improved their TENS related perspective / perception scores when compared to their pre-program scores.

\subsection{Design \& Setting}

A quasi-experimental design was used to evaluate an instructional intervention program designed to enhance obstetrics nurses' information and perceptions relating to TENS throughout labor The study was conducted at the OB department at Prince Hussein Bin Abdullah hospital, affiliated to the Ministry of Health, in Amman, Jordan. The free and/or paid services for pregnancy, labor, postpartum patients with different gynecological problems, and infertility treatments in an addition family planning unit possess, in total, a capacity of thirty five beds.

\subsection{Subjects and methods}

All 65 nurses operating within the OB department at Prince Hussein Bin Abdullah hospital were invited and all agreed to participate in the study.

\subsection{Tools of data collection}

(1). Structured interview questionnaires: based on reviewing the related literature considering the aim of the study it was directed in simple clear Arabic language and consisted of two parts:

First part included socio-demographic characteristics of age, education, qualifications, and years of expertise in delivery area, as well as data relating to having attended a workshop concerning TENS

Second part covered nurses' information concerning TENS: consisted of five items, involving general information regarding labor pain, physiology of labor pain, factors affecting labor pain, causes of labor pain and non-pharmacological interventions to / management of labor pain.

-Information relating to TENS consisted of eleven items: define TENS machine/ mechanism/ theories/ technique of using/ proper time of using/ places for TENS/ indication/ contraindication/ nursing management before \& during use of TENS/ and ethical considerations of TENS. Finally the research focused on five items regarding employing TENS, including: preparation, components and precautions.

To calculate the participants' scores regarding their knowledge relating to TENS, each question / item was scored as follows: a score of two if the answer was correct; a score of one if the answer was partly or semicorrect, and no grade was given if the answer was 'don't recognize' or it was incorrect.

The total information score of the participant was categorized into: poor information from 0 to 15 , average information from 16 to 32 and good information from 32 to 48 or more

(2). Nurses perception tools relating to TENS: it was used to assess nurses perception relating to TENS included sixteen items, based on reviewing the related literature, in order to assess the nurses' perceptions relating to TENS. Points were allocated as follows: agree 3, neutral 2, and disagree 1. The total scores were hierarchic as follows: negative from 16 to 26 , neutral from 27 to 37 and positive from 38 to 48 .

\section{5. Reliability and validity of the tools:}

A reliability test was applied to establish the internal consistency of the perspective / perception measuring tool, by the administration of the same tool to the same subjects under similar conditions on one or more occasions. The answers obtained from the repeated testing were then compared to establish the level of test-retest 
reliability. Additionally, content validity was tested by a jury of experts in the field of obstetric nursing, so also ascertaining relevance and completeness.

A pilot study was run, which involved seven nurses. It was conducted to evaluate the reliability and content validity, test practicability, legibility, understandability and feasibility of the tools, in order to find potential obstacles and problems that might be faced during data collection. The pilot study also served to estimate the time needed to fill in each form. Based on the findings of the pilot study, necessary modifications were made, and some items related to the ethical issues of TENS were added. The seven nurses in the pilot study were excluded from the main study.

\subsection{Ethical considerations}

Before conducting the study the researcher obtained approval from Ministry of Health, Jordan. Also the researcher obtained written consent from the directors of Prince Hussein Bin Abdullah hospital. Informed consent was obtained from the participants after explaining the aim of the study. Emphasis was placed on each participant's right to withdraw from the research at any time with no negative repercussions. The nurses were also assured that any information obtained during the study would remain confidential and be used for research purposes only

\section{Data were collected from July to December 2016.}

\section{Procedure of the Research}

Assessment: Initially the nurses were interviewed to gather baseline data. At the beginning of the interview the greeted every nurse, explained the aim, duration, and activities of the study and collected each nurse's written consent. Pre-tests were done to assess nurses' information and perspectives relating to TENS. The data obtained throughout this part of the study constituted the base line for more comparisons to evaluate the effect of a TENS related instructional intervention program. Average time for the completion of every interview was between 30 to 40 minutes.

The started planning by incorporating baseline information obtained from pre-test assessments and relevant literature. The instructional intervention was developed by the in the form of a written brochure to compensate for the obstetric nurses' information deficit and negative perceptions relating to TENS. The final objective of the instructional intervention was to enhance nurses' information and perceptions concerning TENS.

Implementation: The duration of the instructional intervention program took sixteen weeks. Included four sessions and was offered in step with working circumstances, as well as the nurses' physical and mental readiness to participate. The sessions were repeated for every subgroup of 5 to 10 nurses. The period of every session lasted for a minimum of ninety minutes as well as periods of debate, complementing and in step with their actions, progress and feedback. At the start of the first session, orientation towards the instructional intervention and its aims took place. Feedback and reminders were offered at the start of every session concerning the previous one. Totally different strategies of teaching were used: illustrations, modified lectures, and brainstorming. Appropriate teaching media, brochure that was distributed to all nurses in the first day of the educational intervention, as well as audio-visual aids, videos, and real objects such as the TENS apparatus.

The researcher carried out the first program effectiveness evaluation immediately after the nurse's last session of implementation of the instructional intervention program, and then 3 months later. The follow up check for nurses' information and perception was done byconstant format of the pre-test to evaluate the impact of the instructional intervention program.

A major strength of this study is that it represents the first time in Jordan that an investigation has focused on nurses' information, perceptions regarding TENS.

\section{Statistical Analysis}

Data was coded and transformed into a specially designed format suitable for the computer entry process. Data was analyzed by using SPSS version twenty. Descriptive statistics of mean, variance, frequency and percentages were applied. Tests of significance (chi sq. and paired t test) were applied to check the study's two hypotheses. Correlation coefficients were calculated between information and scores. A statistically significant distinction was set at $\mathrm{p}$-value $\leq .05$, and an extremely statistically significant value was set at $\mathrm{p}$-value $\leq .001$.

\section{Results}

5.1. Table one shows the research population's socio-demographic characteristics. It was found that $61.54 \%$ of the nurses were aged from $20-25$ years, with a mean age of $25.34 \pm 4.51$ years. $69.23 \%$ of the nurses were qualified midwives; $58.46 \%$ had experience within the delivery area ranging from 5-10 years, with a mean of 6.36 years \pm 2.75 years 
5.2. Table two illustrates nurses' information concerning issues relating to labor pain. It was found that had correctly complete answers increased to $92.31 \%, 89.23 \%, 84.62 \%$, and $84.62 \%$, at immediately after intervention and slightly decreased after three months of intervention and there was highly statistically significant difference at different times of assessment.

5.3. Table three displays that there have been highly statistically significant variations between before, immediately after, and 3 months after implementing instructional intervention regarding 65 obstetric nurses' information relating to TENS

5.4. Table four demonstrates low levels of agreement upon all positive statements before intervention. However, immediately after and 3 months after the intervention program the nurses showed significantly positive enhancements in their perceptions regarding TENS. There were highly statistically significant variations immediately after, and 3 months after implementing the academic intervention program. 5.5. Table five shows that there was a statistically significant negative correlation between total information, perceptions scores and age. On the other hand, there was a statistically significant positive correlation between the nurses' total information, total perceptions scores and instructional intervention levels. Moreover, there was also a statistically significant correlation between total information scores and total perceptions scores at different times of the assessments.

5.6. Figure one illustrates that ninety three percent of the nurses had poor TENS-related information levels before being exposed to the intervention program. However, immediately after intervention, ninety four percent of the participants attained good information levels; a total that declined to eighty five percent three months post-intervention.

5.7. Figure two illustrates that only one percent had positive perceptions toward TENS use before being exposed to the instructional intervention program. Immediately after the program $80 \%$ of the nurses registered positive TENS-related views; however, it is notable that after 3 months the total had increased by another $5 \%$ to $85 \%$.

\section{Discussion}

This study was administrated to evaluate an instructional intervention program designed to provide obstetrics nurses in Jordan with information relating to TENS and its use with pain management throughout labor. These results regard's nurses' information about labor pain it was found that had correctly complete answers increased to $92.31 \%, 89.23 \%, 84.62 \%$, and $84.62 \%$, at immediately after intervention and slightly decreased and after three months of intervention and there was support the stated study hypothesis one of obstetrics nurses who received an instructional intervention program would have improved levels of information and understanding concerning TENS, compared to their levels before the program.

Caring for women in labor, particularly relating to pain control and management depends on the implementation of information relating to TENS among OB nurses (working in maternity units in Jordan and throughout the world). Generally the participants in this study possessed little or no knowledge about TENS, and its beneficial effect upon pain management during labor, before they took part in the instructional intervention program. However, the OB nurses' low information scores could also be attributed to the fact that TENS was a new advanced approach to pain management throughout labor. It should be noted that immediately post-test, and 3 months after implementing the tutorial intervention, there was a statistically vital improvement in the information scores in relation to: a) labor pain, b) factors affecting labor pain and c) the technique for using TENS. The nurse participants had good information about TENS after their learning experience. Such an improvement can be accounted for if considering the nurses' professional interest in acquiring information concerning the study topic.

The specifically designed written brochure distributed to the participant nurses, which was also used as an associate degree current reference source, was additionally useful in facilitating the nurses' acquisition of TENS-related information. Additionally, adult learning rules were applied throughout the tutorial sessions, which were designed to encourage the nurse-learners to ask questions, to facilitate active learner participation and interaction throughout the intervention program.

Other researchers have investigated the role of intervention programs used within the field of obstetrics. Akshatha ${ }^{11}$ noted a big distinction between the nurse participants' pre-test and post-test levels of information and reported that a structured teaching program was effective in increasing the information levels of nurses relating to non-pharmacological strategies pertinent to the initial stage of labor.

These findings were supported by Armson ${ }^{12}$ who stressed that perinatal care providers ought to be told and tutored about any promising new clinical approaches, such as TENS, which could be used to relieve labor pain. Such interventions were particularly helpful to the nurse-learners when supported by sound scientific evidence.

In the current study, it revealed that decrease at intervals the mean variant scores among nurses information after three months is often called the retention of information over time. These findings were supported by Hend \& Mohammed ${ }^{13}$. However, these variant scores remained high, compared to the 
nurses' initial scores before experiencing their instructional intervention program. These findings were supported by Emery et al. ${ }^{1314}$ who noticed an instantaneous relationship between memory attrition and length of your time that elapsed after exposure to instructional intervention program. Concerning nurses' perceptions towards TENS, the findings of the present study revealed that two thirds of the studied nurses had negative perceptions of TENS before attending the instructional intervention program. However, after attending the intervention program more than two thirds of the nurses registered positive views about TENS and its usefulness. These positive perceptions were still expressed three months after the program had ended. Such views might be the result of receiving information via an instructional intervention program, combined with the nurses' high adherence to, and active participation in, the tutorial sessions. Such activities thereby improved their TENS information levels, resulting in the formation of additional TENS-related positive perceptions; findings that are in line with Vincent. ${ }^{15}$ However, Bombas et al., ${ }^{16}$ in their study, found nurses' perceptions showed very little positive improvement; the researchers encountered difficulties in changing the participant nurses' perceptions. In general, the OB nurses within the current study at first registered poor TENSrelated information scores, with high levels of negative perceptions. Implementing an academic intervention that met their desires proved extremely helpful in fostering their information levels and changing their views and opinions about TENS in a positive and more accepting direction. Such outcomes allow the two hypotheses of the present study to be accepted hypothesis.

The effectiveness of the tutorial intervention program, and its positive influence on OB nurses' information and perceptions towards TENS, were apparent from the results. The findings support the results of Chen and Lou, ${ }^{17}$ whose systematic review discovered that such programs are helpful, particularly if they involve multi-dimensional teaching ways. Moreover, Varghese ${ }^{18}$ added that nurses have a vital role to play throughout a woman's labor. The nursing information ought to embody current new approaches used throughout the care of parturient women, so as to update information relating to recent relevant advances. From the evidence-based practice obtained during this current study, it is reasonable to argue that a structured teaching program is one of the more practical strategies to enable individual learners, as the participant nurses in this study, to both acquire and impart information. Putting group action information into perceptions, this analysis has revealed a positive and statistically significant correlation between information and perceptions; with improved information being related to positive changes on the nurses' perceptions. This finding was anticipated and is according to the findings of Askarian et al. 19 who identified a linear correlation between information and perceptions scores of the OB nurses who were studied. In addition, the findings of the present study illustrated that there was a statistically significant correlation between total information, total perceptions scores and age, and years of experience at totally different times of assessment. This can be because of OB nurses who have additional experience are effective for activities, over and on top of their patient-contact during labor.

\section{Conclusion}

In the light of the study findings, it can be concluded that there was a statistically significant improvement in the mean scores of OB nurses' TENS-related information, both immediately, and at 3 months, post-intervention. There was additionally a statistically significant distinction in nurses' perspective scores before, immediately after, and 3 months post experiencing the specifically designed TENS-related academic intervention program. The implementation of an academic intervention program was effective and considerably improved nurses' information and perceptions towards TENS throughout traditional labor.

\section{Recommendations}

The nursing information ought to embody knowledge concerning present technologies to update their awareness and understanding of recent advances in TENS. Easy-to-understand booklets relating to the efficacy of TENS throughout labor should be available with quick access throughout all labor units.

\section{Acknowledgements}

We wish to convey our sincere thanks to the administration of the Philadelphia University, Prince Hussein Bin Abdullah hospital, and every one the nurses in the labor unit within the OB department, for facilitating and / or participating in this study.

Funding: this project was supported by a grant from the Philadelphia University, Jordan, 2016. 
Efficacy of an Instructional Intervention Program on Obstetric Nurses' Information and ..

Table1: Distribution of the studied nurses according to their general characteristics $(n=65)$

\begin{tabular}{|l|l|l|}
\hline Characteristics parameters & No. & $\%$ \\
\hline Age (years) & & \\
$<20$ & 4 & 6.15 \\
$20-25$ & 40 & 61.54 \\
$26-30$ & 15 & 23.08 \\
$>30$ & 6 & 9.23 \\
Mean \pm SD & $25.34 \pm 4.51$ & \\
\hline Qualification & & \\
Midwifery & 45 & 69.23 \\
Bachelor of nursing & 20 & 30.77 \\
\hline Years of experience & & \\
$<5$ & 17 & 26.15 \\
$5-10$ & 38 & 58.46 \\
$>10$ & 10 & 15.38 \\
Mean \pm SD & $6.36 \pm 2.75$ & \\
\hline Previous attendance of training courses about TENS & & \\
Yes & & \\
No & 0 & 00.00 \\
& 65 & 100.00 \\
\hline
\end{tabular}

Table2: Distribution of the studied sample according to their information regarding labor pain at different times

\begin{tabular}{|c|c|c|c|c|c|c|c|c|}
\hline \multicolumn{9}{|c|}{ assessment $(\mathrm{n}=65)$} \\
\hline Variables & No & $\%$ & No & $\%$ & No & $\%$ & & \\
\hline $\begin{array}{l}\text { Causes of labor pain } \\
\text { Correct } \\
\text { Partly correct } \\
\text { Don't know }\end{array}$ & $\begin{array}{l}15 \\
20 \\
30\end{array}$ & $\begin{array}{l}23.08 \\
30.77 \\
46.15\end{array}$ & $\begin{array}{l}58 \\
7 \\
0\end{array}$ & $\begin{array}{l}8.23 \\
10.77 \\
00.00\end{array}$ & $\begin{array}{l}56 \\
7 \\
2\end{array}$ & $\begin{array}{l}86.15 \\
10.77 \\
3.08\end{array}$ & 90.0865 & $<0.00001^{*}$ \\
\hline $\begin{array}{l}\text { Physiology of labor pain } \quad \text { Correct } \\
\text { Partly correct } \\
\text { Don't know }\end{array}$ & $\begin{array}{l}18 \\
14 \\
33\end{array}$ & $\begin{array}{l}27.69 \\
21.54 \\
50.77\end{array}$ & $\begin{array}{l}55 \\
9 \\
1\end{array}$ & $\begin{array}{l}84.62 \\
13.84 \\
1.54\end{array}$ & $\begin{array}{l}59 \\
4 \\
2\end{array}$ & $\begin{array}{l}90.77 \\
6.15 \\
3.08\end{array}$ & 83.9495 & $<0.00001^{*}$ \\
\hline $\begin{array}{l}\text { Theory of labor pain } \\
\text { Correct } \\
\text { Partly correct } \\
\text { Don't know }\end{array}$ & $\begin{array}{l}7 \\
15 \\
43\end{array}$ & $\begin{array}{l}10.77 \\
23.08 \\
66.15\end{array}$ & $\begin{array}{l}55 \\
10 \\
0\end{array}$ & $\begin{array}{l}84.62 \\
15.38 \\
00.00\end{array}$ & $\begin{array}{l}58 \\
5 \\
2\end{array}$ & $\begin{array}{l}89.23 \\
7.69 \\
3.08\end{array}$ & 124.4833 & $<0.00001 *$ \\
\hline $\begin{array}{l}\text { Factors affecting labor pain } \\
\text { Correct } \\
\text { Partly correct } \\
\text { Don't know }\end{array}$ & $\begin{array}{l}10 \\
20 \\
35\end{array}$ & $\begin{array}{l}15.38 \\
30.77 \\
53.85\end{array}$ & $\begin{array}{l}60 \\
5 \\
0\end{array}$ & $\begin{array}{l}92.31 \\
7.69 \\
00.00\end{array}$ & $\begin{array}{l}60 \\
4 \\
1\end{array}$ & $\begin{array}{l}92.31 \\
6.15 \\
1.54\end{array}$ & 121.2489 & $<0.00001^{*}$ \\
\hline $\begin{array}{l}\text { Non pharmacological interventions } \\
\text { to labor pain } \\
\text { Correct } \\
\text { Partly correct } \\
\text { Don't know }\end{array}$ & $\begin{array}{l}10 \\
20 \\
35\end{array}$ & $\begin{array}{l}15.38 \\
30.77 \\
53.85\end{array}$ & $\begin{array}{l}55 \\
10 \\
0\end{array}$ & $\begin{array}{l}84.62 \\
15.38 \\
00.00\end{array}$ & $\begin{array}{l}59 \\
6 \\
0\end{array}$ & $\begin{array}{l}90.77 \\
9.23 \\
00.00\end{array}$ & 114.4892 & $<0.00001^{*}$ \\
\hline
\end{tabular}

Significant $(*)$ at $\mathrm{p}<0.05$

Table3: Distribution of the study's population according to their information relating to TENS at different times of assessment $(n=65)$

\begin{tabular}{|c|c|c|c|c|c|c|c|c|}
\hline & Bef & & $\begin{array}{l}\text { Imm } \\
\text { after }\end{array}$ & diately & After & months & $\chi^{2}$ & $P$ value \\
\hline Variables & No & $\%$ & No & $\%$ & No & $\%$ & & \\
\hline $\begin{array}{l}\text { Define TENS machine } \\
\text { Correct } \\
\text { Partly correct } \\
\text { Don't know }\end{array}$ & $\begin{array}{l}0 \\
0 \\
65\end{array}$ & $\begin{array}{l}00.00 \\
00.00 \\
100.00\end{array}$ & $\begin{array}{l}58 \\
7 \\
0 \\
\end{array}$ & $\begin{array}{l}89.23 \\
10.77 \\
00.00\end{array}$ & $\begin{array}{l}56 \\
7 \\
2 \\
\end{array}$ & $\begin{array}{l}86.15 \\
10.77 \\
3.08\end{array}$ & 186.4108 & $<0.00001^{*}$ \\
\hline $\begin{array}{l}\text { Discuss mechanism of TENS Correct } \\
\text { Partly correct } \\
\text { Don't know }\end{array}$ & $\begin{array}{l}0 \\
0 \\
65 \\
\end{array}$ & $\begin{array}{l}00.00 \\
00.00 \\
100.00 \\
\end{array}$ & $\begin{array}{l}55 \\
9 \\
1 \\
\end{array}$ & $\begin{array}{l}84.62 \\
13.84 \\
1.54 \\
\end{array}$ & $\begin{array}{l}59 \\
4 \\
2 \\
\end{array}$ & $\begin{array}{l}90.77 \\
6.15 \\
3.08 \\
\end{array}$ & 185.2128 & $<0.00001^{*}$ \\
\hline $\begin{array}{l}\text { TENS theories } \\
\text { Correct } \\
\text { Partly correct } \\
\text { Don't know }\end{array}$ & $\begin{array}{l}0 \\
0 \\
65 \\
\end{array}$ & $\begin{array}{l}00.00 \\
00.00 \\
100.00 \\
\end{array}$ & $\begin{array}{l}55 \\
10 \\
0\end{array}$ & $\begin{array}{l}84.62 \\
15.38 \\
00.00\end{array}$ & $\begin{array}{l}58 \\
5 \\
2 \\
\end{array}$ & $\begin{array}{l}89.23 \\
7.69 \\
3.08 \\
\end{array}$ & 188.9777 & $<0.00001^{*}$ \\
\hline $\begin{array}{l}\text { Identify proper time of using TENS } \\
\text { Correct } \\
\text { Partly correct } \\
\text { Don't know }\end{array}$ & $\begin{array}{l}0 \\
0 \\
65 \\
\end{array}$ & $\begin{array}{l}00.00 \\
00.00 \\
100.00 \\
\end{array}$ & $\begin{array}{l}60 \\
5 \\
0 \\
\end{array}$ & $\begin{array}{l}92.31 \\
7.69 \\
00.00 \\
\end{array}$ & $\begin{array}{l}60 \\
4 \\
1 \\
\end{array}$ & $\begin{array}{l}92.31 \\
6.15 \\
1.54 \\
\end{array}$ & 190.7576 & $<0.00001^{*}$ \\
\hline
\end{tabular}


Efficacy of an Instructional Intervention Program on Obstetric Nurses' Information and ..

\begin{tabular}{|c|c|c|c|c|c|c|c|c|}
\hline $\begin{array}{l}\text { labor } \\
\text { Correct } \\
\text { Partly correct } \\
\text { Don't know } \\
\end{array}$ & $\begin{array}{l}0 \\
0 \\
65 \\
\end{array}$ & $\begin{array}{l}00.00 \\
00.00 \\
100.00\end{array}$ & $\begin{array}{l}55 \\
10 \\
0 \\
\end{array}$ & $\begin{array}{l}84.62 \\
15.38 \\
00.00 \\
\end{array}$ & $\begin{array}{l}59 \\
6 \\
0 \\
\end{array}$ & $\begin{array}{l}90.77 \\
9.23 \\
00.00 \\
\end{array}$ & 196.7105 & $<0.00001 *$ \\
\hline $\begin{array}{l}\text { Mention places and length time for } \\
\text { TENS } \\
\text { Correct } \\
\text { Partly correct } \\
\text { Don't know }\end{array}$ & $\begin{array}{l}0 \\
0 \\
65\end{array}$ & $\begin{array}{l}00.00 \\
00.00 \\
100.00\end{array}$ & $\begin{array}{l}58 \\
7 \\
0\end{array}$ & $\begin{array}{l}89.23 \\
10.77 \\
00.00\end{array}$ & $\begin{array}{l}56 \\
7 \\
2\end{array}$ & $\begin{array}{l}86.15 \\
10.77 \\
3.08\end{array}$ & 186.4108 & $<0.00001^{*}$ \\
\hline $\begin{array}{l}\text { Technique of using TENS } \\
\text { Correct } \\
\text { Partly correct } \\
\text { Don't know }\end{array}$ & $\begin{array}{l}0 \\
0 \\
65 \\
\end{array}$ & $\begin{array}{l}00.00 \\
00.00 \\
100.00\end{array}$ & $\begin{array}{l}55 \\
9 \\
1 \\
\end{array}$ & $\begin{array}{l}84.62 \\
13.84 \\
1.54 \\
\end{array}$ & $\begin{array}{l}59 \\
4 \\
2 \\
\end{array}$ & $\begin{array}{l}90.77 \\
6.15 \\
3.08 \\
\end{array}$ & 185.2128 & $<0.00001 *$ \\
\hline $\begin{array}{l}\text { Indication of using TENS } \\
\text { Correct } \\
\text { Partly correct } \\
\text { Don't know }\end{array}$ & $\begin{array}{l}0 \\
0 \\
65 \\
\end{array}$ & $\begin{array}{l}00.00 \\
00.00 \\
100.00\end{array}$ & $\begin{array}{l}55 \\
10 \\
0\end{array}$ & $\begin{array}{l}84.62 \\
15.38 \\
00.00\end{array}$ & $\begin{array}{l}58 \\
5 \\
2 \\
\end{array}$ & $\begin{array}{l}89.23 \\
7.69 \\
3.08 \\
\end{array}$ & 188.9777 & $<0.00001 *$ \\
\hline $\begin{array}{l}\text { Contraindication of using TENS } \\
\text { Correct } \\
\text { Partly correct } \\
\text { Don't know }\end{array}$ & $\begin{array}{l}4 \\
11 \\
50 \\
\end{array}$ & $\begin{array}{l}6.15 \\
15.38 \\
76.92 \\
\end{array}$ & $\begin{array}{l}60 \\
5 \\
0 \\
\end{array}$ & $\begin{array}{l}92.31 \\
7.69 \\
00.00 \\
\end{array}$ & $\begin{array}{l}60 \\
4 \\
1 \\
\end{array}$ & $\begin{array}{l}92.31 \\
6.15 \\
1.54 \\
\end{array}$ & 150.9983 & $<0.00001 *$ \\
\hline $\begin{array}{l}\text { Nursing management before \& during } \\
\text { applied the TENS. } \\
\text { Correct } \\
\text { Partly correct } \\
\text { Don't know }\end{array}$ & $\begin{array}{l}0 \\
0 \\
65\end{array}$ & $\begin{array}{l}00.00 \\
00.00 \\
100.00\end{array}$ & $\begin{array}{l}55 \\
10 \\
0\end{array}$ & $\begin{array}{l}84.62 \\
15.38 \\
00.00\end{array}$ & $\begin{array}{l}59 \\
6 \\
0\end{array}$ & $\begin{array}{l}90.77 \\
9.23 \\
00.00\end{array}$ & 196.7105 & $<0.00001 *$ \\
\hline $\begin{array}{l}\text { Ethical considerations of obtaining } \\
\text { TENS } \\
\text { Correct } \\
\text { Partly correct } \\
\text { Don't know } \\
\end{array}$ & $\begin{array}{l}0 \\
5 \\
60 \\
\end{array}$ & $\begin{array}{l}00.00 \\
7.69 \\
92.31 \\
\end{array}$ & $\begin{array}{l}60 \\
4 \\
1 \\
\end{array}$ & $\begin{array}{l}92.31 \\
6.15 \\
1.54 \\
\end{array}$ & $\begin{array}{l}60 \\
5 \\
0 \\
\end{array}$ & $\begin{array}{l}92.31 \\
7.69 \\
00.00 \\
\end{array}$ & 176.2412 & $<0.00001^{*}$ \\
\hline
\end{tabular}

Significant $(*)$ at $\mathrm{p}<0.05$

Table4: Distribution of the studied sample according to their perceptions toward the efficacy of TENS at different times of assessment $(n=65)$

\begin{tabular}{|c|c|c|c|c|c|c|c|c|}
\hline Variable of perceptions & $\begin{array}{c} \\
\text { No } \\
\end{array}$ & $\%$ & & $\begin{array}{l}\text { diately } \\
\text { ter }\end{array}$ & Aft & months & $\chi^{2}$ & $P$ value \\
\hline $\begin{array}{l}\text { Positive } \\
\text { Neutral } \\
\text { Negative }\end{array}$ & $\begin{array}{c}1 \\
4 \\
60 \\
\end{array}$ & $\begin{array}{c}1.54 \\
6.15 \\
92.31 \\
\end{array}$ & $\begin{array}{c}57 \\
5 \\
3 \\
\end{array}$ & $\begin{array}{c}87.69 \\
7.69 \\
4.62 \\
\end{array}$ & $\begin{array}{c}55 \\
8 \\
2 \\
\end{array}$ & $\begin{array}{c}84.62 \\
12.31 \\
3.07 \\
\end{array}$ & 156.8762 & $<0.00001 *$ \\
\hline $\begin{array}{c}\text { TENS available for women during labor } \\
\text { Positive } \\
\text { Neutral } \\
\text { Negative }\end{array}$ & $\begin{array}{c}2 \\
3 \\
60 \\
\end{array}$ & $\begin{array}{c}3.08 \\
4.61 \\
92.31 \\
\end{array}$ & $\begin{array}{c}52 \\
10 \\
3\end{array}$ & $\begin{array}{c}80.00 \\
15.38 \\
4.62 \\
\end{array}$ & $\begin{array}{c}50 \\
10 \\
5\end{array}$ & $\begin{array}{c}76.92 \\
15.38 \\
7.70 \\
\end{array}$ & 142.8152 & $<0.00001 *$ \\
\hline $\begin{array}{c}\text { TENS should only be used for labor pain } \\
\text { Positive } \\
\text { Neutral } \\
\text { Negative }\end{array}$ & $\begin{array}{c}2 \\
8 \\
55\end{array}$ & $\begin{array}{c}3.08 \\
12.31 \\
84.61 \\
\end{array}$ & $\begin{array}{c}43 \\
15 \\
7 \\
\end{array}$ & $\begin{array}{l}66.15 \\
23.08 \\
10.77 \\
\end{array}$ & $\begin{array}{c}35 \\
25 \\
5\end{array}$ & $\begin{array}{c}53.85 \\
38.45 \\
7.70 \\
\end{array}$ & 116.3112 & $<0.00001 *$ \\
\hline $\begin{array}{c}\text { TENS is noninvasive } \\
\text { Positive } \\
\text { Neutral } \\
\text { Negative } \\
\end{array}$ & $\begin{array}{c}3 \\
10 \\
52 \\
\end{array}$ & $\begin{array}{c}4.62 \\
15.38 \\
80 \\
\end{array}$ & $\begin{array}{c}65 \\
0 \\
0 \\
\end{array}$ & $\begin{array}{c}100.00 \\
0 \\
0 \\
\end{array}$ & $\begin{array}{c}65 \\
0 \\
0 \\
\end{array}$ & $\begin{array}{c}100.00 \\
0 \\
0 \\
\end{array}$ & 181.8045 & $<0.00001 *$ \\
\hline $\begin{array}{c}\text { TENS is wasting time. } \\
\text { Positive } \\
\text { Neutral } \\
\text { Negative }\end{array}$ & $\begin{array}{l}15 \\
20 \\
30\end{array}$ & $\begin{array}{l}23.08 \\
30.77 \\
46.15\end{array}$ & $\begin{array}{c}60 \\
5 \\
0\end{array}$ & $\begin{array}{c}92.31 \\
7.69 \\
0\end{array}$ & $\begin{array}{c}58 \\
5 \\
2 \\
\end{array}$ & $\begin{array}{c}89.23 \\
7.70 \\
3.07\end{array}$ & 96.9079 & $<0.00001 *$ \\
\hline $\begin{array}{c}\text { TENS would be used } \\
\text { for different purposes. } \\
\text { Positive } \\
\text { Neutral } \\
\text { Negative }\end{array}$ & $\begin{array}{c}3 \\
10 \\
52 \\
\end{array}$ & $\begin{array}{c}4.62 \\
15.38 \\
80 \\
\end{array}$ & $\begin{array}{c}50 \\
10 \\
5\end{array}$ & $\begin{array}{c}76.92 \\
15.38 \\
7.70 \\
\end{array}$ & $\begin{array}{c}52 \\
8 \\
5\end{array}$ & $\begin{array}{c}80 \\
12.30 \\
7.70 \\
\end{array}$ & 115.4866 & $<0.00001^{*}$ \\
\hline $\begin{array}{c}\text { TENS affect the care of mother or fetus } \\
\text { Positive } \\
\text { Neutral } \\
\text { Negative }\end{array}$ & $\begin{array}{l}15 \\
10 \\
40\end{array}$ & $\begin{array}{l}23.08 \\
15.38 \\
61.54 \\
\end{array}$ & $\begin{array}{c}48 \\
15 \\
2\end{array}$ & $\begin{array}{c}73.85 \\
23.07 \\
3.08 \\
\end{array}$ & $\begin{array}{c}45 \\
19 \\
1\end{array}$ & $\begin{array}{c}69.23 \\
29.23 \\
1.54 \\
\end{array}$ & 90.2495 & $<0.00001 *$ \\
\hline $\begin{array}{c}\text { TENS should be included as a routine care } \\
\text { in delivery rooms } \\
\text { Positive }\end{array}$ & 1 & 1.54 & 50 & 76.92 & 45 & 69.24 & & \\
\hline
\end{tabular}


Efficacy of an Instructional Intervention Program on Obstetric Nurses' Information and ..

\begin{tabular}{|c|c|c|c|c|c|c|c|c|}
\hline $\begin{array}{c}\text { Neutral } \\
\text { Negative }\end{array}$ & $\begin{array}{l}20 \\
44 \\
\end{array}$ & $\begin{array}{l}30.77 \\
67.69 \\
\end{array}$ & $\begin{array}{c}10 \\
5\end{array}$ & $\begin{array}{c}15.38 \\
7.70 \\
\end{array}$ & $\begin{array}{l}10 \\
10 \\
\end{array}$ & $\begin{array}{l}15.38 \\
15.38 \\
\end{array}$ & 96.2341 & $<0.00001^{*}$ \\
\hline $\begin{array}{c}\text { Experiences and proficiency is required for } \\
\text { TENS use } \\
\text { Positive } \\
\text { Neutral } \\
\text { Negative }\end{array}$ & $\begin{array}{c}5 \\
11 \\
49\end{array}$ & $\begin{array}{c}7.7 \\
16.92 \\
75.38\end{array}$ & $\begin{array}{c}55 \\
5 \\
5\end{array}$ & $\begin{array}{c}84.62 \\
7.69 \\
7.69\end{array}$ & $\begin{array}{c}50 \\
10 \\
5\end{array}$ & $\begin{array}{c}76.92 \\
15.38 \\
7.70\end{array}$ & 109.3754 & $<0.00001 *$ \\
\hline $\begin{array}{c}\text { Think it is necessary to perform TENS } \\
\text { before use } \\
\text { Positive } \\
\text { Neutral } \\
\text { Negative } \\
\end{array}$ & $\begin{array}{l}17 \\
10 \\
38 \\
\end{array}$ & $\begin{array}{l}26.15 \\
15.39 \\
58.46 \\
\end{array}$ & $\begin{array}{c}45 \\
15 \\
5 \\
\end{array}$ & $\begin{array}{c}69.23 \\
23.07 \\
7.70 \\
\end{array}$ & $\begin{array}{c}40 \\
20 \\
5 \\
\end{array}$ & $\begin{array}{c}61.53 \\
30.77 \\
7.70 \\
\end{array}$ & 61.826 & $<0.00001^{*}$ \\
\hline $\begin{array}{c}\text { Think it is necessary to have TENS stored. } \\
\text { Positive } \\
\text { Neutral } \\
\text { Negative }\end{array}$ & $\begin{array}{l}32 \\
10 \\
23 \\
\end{array}$ & $\begin{array}{l}49.23 \\
15.39 \\
35.38 \\
\end{array}$ & $\begin{array}{c}55 \\
5 \\
5 \\
\end{array}$ & $\begin{array}{c}84.62 \\
7.69 \\
7.69 \\
\end{array}$ & $\begin{array}{c}45 \\
15 \\
5 \\
\end{array}$ & $\begin{array}{c}69.23 \\
23.07 \\
7.70 \\
\end{array}$ & 30.6818 & $<0.00001 *$ \\
\hline $\begin{array}{c}\text { It is necessary to introduce TENS } \\
\text { in antenatal care. } \\
\text { Positive } \\
\text { Neutral } \\
\text { Negative }\end{array}$ & $\begin{array}{c}2 \\
20 \\
43\end{array}$ & $\begin{array}{c}3.08 \\
30.77 \\
66.15\end{array}$ & $\begin{array}{c}48 \\
12 \\
5\end{array}$ & $\begin{array}{c}73.85 \\
18.46 \\
7.69\end{array}$ & $\begin{array}{l}40 \\
15 \\
10\end{array}$ & $\begin{array}{l}61.54 \\
23.08 \\
15.38\end{array}$ & 86.4552 & $<0.00001 *$ \\
\hline $\begin{array}{c}\text { Think it is necessary to prepare the } \\
\text { mother's position before TENS used. } \\
\text { Positive } \\
\text { Neutral } \\
\text { Negative } \\
\end{array}$ & $\begin{array}{l}24 \\
10 \\
31 \\
\end{array}$ & $\begin{array}{l}36.92 \\
15.39 \\
47.69 \\
\end{array}$ & $\begin{array}{c}55 \\
10 \\
0 \\
\end{array}$ & $\begin{array}{c}84.62 \\
15.38 \\
0 \\
\end{array}$ & $\begin{array}{c}45 \\
15 \\
5 \\
\end{array}$ & $\begin{array}{c}69.23 \\
23.07 \\
7.70 \\
\end{array}$ & 59.7081 & $<0.00001 *$ \\
\hline $\begin{array}{c}\text { Accept to attend workshops about TENS } \\
\text { Positive } \\
\text { Neutral } \\
\text { Negative }\end{array}$ & $\begin{array}{c}5 \\
5 \\
55 \\
\end{array}$ & $\begin{array}{c}7.69 \\
7.69 \\
84.62\end{array}$ & $\begin{array}{c}64 \\
1 \\
0 \\
\end{array}$ & $\begin{array}{c}98.46 \\
1.54 \\
0 \\
\end{array}$ & $\begin{array}{c}57 \\
5 \\
3 \\
\end{array}$ & $\begin{array}{c}87.70 \\
7.70 \\
4.60\end{array}$ & 151.3163 & $<0.00001^{*}$ \\
\hline $\begin{array}{c}\text { TENS is approved by doctors. } \\
\text { Positive } \\
\text { Neutral } \\
\text { Negative } \\
\end{array}$ & $\begin{array}{l}20 \\
20 \\
25\end{array}$ & $\begin{array}{l}30.77 \\
30.77 \\
38.46\end{array}$ & $\begin{array}{c}55 \\
5 \\
5\end{array}$ & $\begin{array}{c}84.62 \\
7.69 \\
7.69 \\
\end{array}$ & $\begin{array}{c}60 \\
3 \\
2 \\
\end{array}$ & $\begin{array}{c}92.31 \\
4.60 \\
3.09\end{array}$ & 68.9236 & $<0.00001^{*}$ \\
\hline
\end{tabular}

Table5: Mean subtotal and total information scores of the studied sample at different times of assessment $(\mathrm{n}=65)$

\begin{tabular}{|c|c|c|c|c|c|c|c|c|}
\hline Information about & $\begin{array}{l}\text { Maximum } \\
\text { score }\end{array}$ & Before & $\begin{array}{l}\text { Immediately } \\
\text { after }\end{array}$ & $\begin{array}{l}\text { Paired t1 } \\
\text { test }\end{array}$ & p value & $\begin{array}{ll}\text { After } & 3 \\
\text { months } & \end{array}$ & $\begin{array}{l}\text { Paired t1 } \\
\text { test }\end{array}$ & p value \\
\hline Labor pain & 10 & $3.28 \pm 2.05$ & $9.21 \pm 1.04$ & 16.354 & $<.001 * *$ & $8.73 \pm 1.29$ & 23.012 & $<.001 * *$ \\
\hline Theory of labor pain & 20 & $2.92 \pm 2.64$ & $16.36 \pm 1.63$ & 18.284 & $<.001 * *$ & $14.85 \pm 1.71$ & 27.937 & $<.001 * *$ \\
\hline Benefits of using TENS & 10 & $1.32 \pm 1.22$ & $8.92 \pm 1.21$ & 37.750 & $<.001 * *$ & $7.81 \pm 1.49$ & 31.321 & $<.001 * *$ \\
\hline Technique of using TENS & 10 & $1.19 \pm 1.03$ & $8.74 \pm 1.33$ & 27.149 & $<.001 * *$ & $7.91 \pm 1.43$ & 33.416 & $<.001 * *$ \\
\hline Total & 50 & $8.72 \pm 5.95$ & $43.23 \pm 4.15$ & 41.919 & $<.001 * *$ & $39.79 \pm 3.95$ & 34.768 & $<.001 * *$ \\
\hline
\end{tabular}

$\left({ }^{* *}\right)$ A highly statistically significant difference $(\mathrm{P} \leq .001)$; Paired $\mathrm{t} 1$ test (between before and immediately after); Paired t 2 test (between before and after 3 months)

Table6: Correlation coefficients between total information, perceptions scores regarding efficacy of TENS and demographic characteristics of the studied sample at different times of assessment $(n=65)$

\begin{tabular}{|c|c|c|c|c|c|c|}
\hline \multirow[b]{2}{*}{$\begin{array}{l}\text { Total knowledge score: } \\
\text { Before } \\
\text { Immediately after } \\
\text { After } 3 \text { months }\end{array}$} & \multicolumn{2}{|l|}{ Age } & \multicolumn{2}{|c|}{$\begin{array}{ll}\begin{array}{l}\text { Years } \\
\text { experience }\end{array} & \text { of } \\
\end{array}$} & \multicolumn{2}{|c|}{ Educational level } \\
\hline & $\begin{array}{l}-0.452 \\
-0.510 \\
0.644 \\
\end{array}$ & $\begin{array}{l}<.01 * * \\
<.01 * * \\
<.01 * *\end{array}$ & $\begin{array}{l}-0.528 \\
-0.529 \\
0.728\end{array}$ & $\begin{array}{l}<.01 * * \\
<.01 * * \\
<.01 * *\end{array}$ & $\begin{array}{l}0.706 \\
0.447 \\
0.600 \\
\end{array}$ & $\begin{array}{l}<.01 * * \\
<.01 * * \\
<.01 * *\end{array}$ \\
\hline $\begin{array}{l}\text { Total attitude score: } \\
\text { Before } \\
\text { Immediately after } \\
\text { After } 3 \text { months }\end{array}$ & $\begin{array}{l}-0.439 \\
0.528 \\
0.546\end{array}$ & $\begin{array}{l}<.01 * * \\
<.01 * * \\
<.01 * *\end{array}$ & $\begin{array}{l}-0.546 \\
-0.603 \\
-0.570\end{array}$ & $\begin{array}{l}<.01 * * \\
<.01 * * \\
<.01 * *\end{array}$ & $\begin{array}{l}0.663 \\
0.424 \\
0.575 \\
\end{array}$ & $\begin{array}{l}<.01 * * \\
<.01 * * \\
<.01 * *\end{array}$ \\
\hline
\end{tabular}


Figure 1: Distribution of the studied sample according to their total information scores at the different times of assessment $(n=65)$

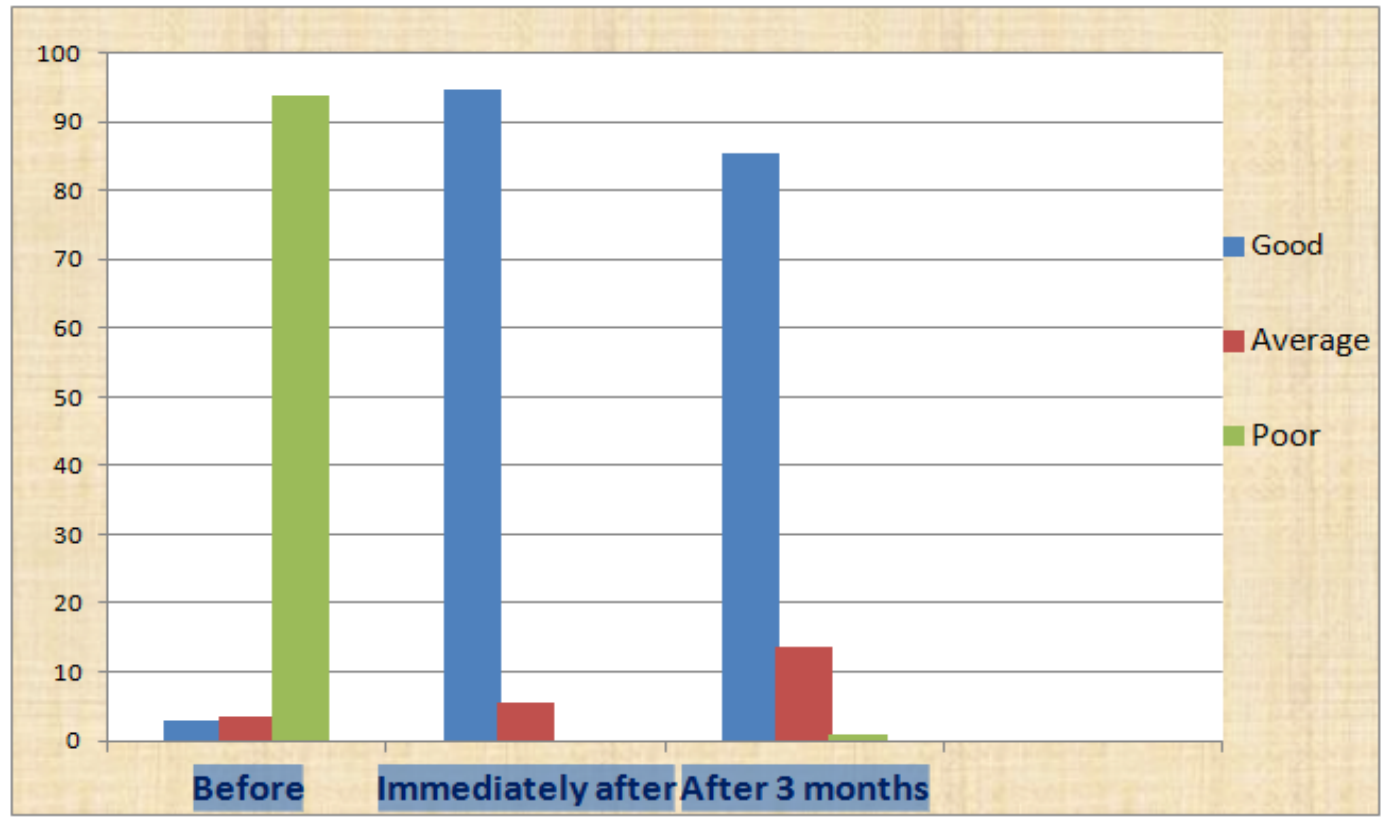

Figure 2: Distribution of the studied sample according to their total perceptions levels at the different times of assessment $(\mathrm{n}=65)$

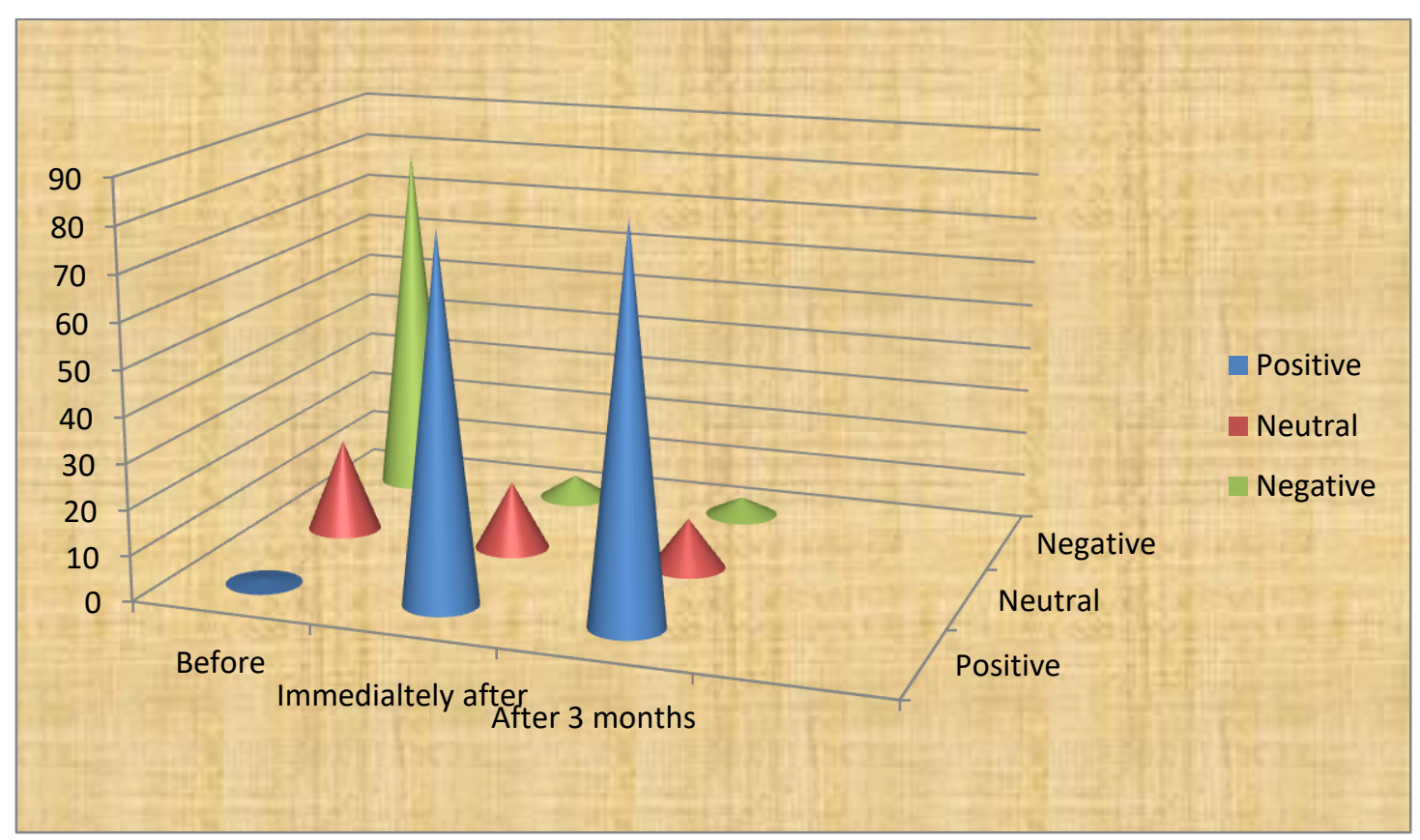




\section{References}

[1]. Higgins JPT, Green S. (20011). Editors. Cochrane Handbook for Systematic Reviews of Interventions Version 5.1.0 [updated March 2011] The Cochrane Collaboration; 2011. Available fromwww.cochrane-handbook.org

[2]. Higgins JPT, Green S. (2008). Editors. Cochrane Handbook for Systematic Reviews of Interventions Version 5.0.0 [updated February 2008] The Cochrane Collaboration; 2008. Available fromwww.cochrane-handbook.org.

[3]. Chao AS, Chao A, Wang TH, Chang YC, Peng HH, Chang SD, et al. (2007). Pain relief by applying transcutaneous electrical nerve stimulation (tens) on acupuncture points during the first stage of labor: a randomized double-blind placebo-controlled trial. Pain. 2007;127(3):214-20. [PubMed]

[4]. Orange FA, Ramos de Amorim MM, Lima L. (2003). The use of transcutaneous nerve stimulation for pain relief during labor in a teaching hospital: a randomized controlled trial Revista Brasileira de Ginecologia e Obstetricia.2003;25(1):45-52.

[5]. Vasegh RF, Seddighian Z. (2010). The effects of TENS , applying on specific acupuncture points versus thoracic-lumbo sacral vertebras on active phase of labor. Journal of Psychsomatic Obstetrics and Gynecology. 2010;31(s1):125.

[6]. Wang B, Xiong X, Li W. (2007). Study on Transcutaneous Electrical Nerve Stimulation (TENS) applied to acupoints for relieving labour pain. International Journal of Clinical Acupuncture. 2007;16(1):7-11.

[7]. Knobel R, Radunz V, Carraro TE. (2005). Use of transcutaneous electric nerve stimulation for pain relief in labour: a possible way to care the child-bearer [Utilizacao de estimulacao eletrica transcutanea para alivio da dor no trabalho de parto: um modo possivel para o cuidado a parturiente] Texto Contexto-Enfermagem. 2005;14(2):229-36.

[8]. Barragán Loayza IM, Solà I, Juandó Prats C. (2011). Biofeedback for pain management during labour. Cochrane Database of Systematic Reviews. 2011;(6) DOI: 10.1002/14651858.CD006168.pub2.[PubMed]

[9]. Deeks JJ, Altman DG, Bradburn MJ. (2001). Statistical methods for examining heterogeneity and combining results from several studies in meta-analysis. In: Egger M, Davey Smith G, Altman DG, editors. Systematic reviews in health care: meta-analysis in context. BMJ Books; London: 2001.

[10]. Derry S, Straube S, Moore RA, Hancock H, Collins SL. (2011). Intracutaneous or subcutaneous sterile water injection for relieving pain in labour. Cochrane Database of Systematic Reviews. 2011;(5) DOI: 10.1002/14651858.CD009107. [PubMed]

[11]. Akshatha, R. (2012). Effectiveness of structured teaching programme on knowledge regarding placental stemcell banking among staff nurses working in selected maternity hospitals, Mangalore. Published M. Sc. Nursing thesis submitted to Rajiv Gandhi University of Health Sciences Karnataka. 2012; 46.

[12]. Armson, E. (2005). Umbilical cord blood banking: implications for perinatal care providers. Journal of Obstetrics and Gynaecology. $2005 ; 27(3): 263-290$.

[13]. Hend S. Mohammed. (2015). Knowledge and attitude of maternity nurses regarding cord blood collection and stem cells: An educational intervention. Journal of Nursing Education and Practice 2015, Vol. 5, No. 4:58-68

[14]. Emery, S., Labeeb. S. Marzouk, S. and Hussien, A. (2013). An In-service Training Program about Nursing Care of children with poisoning at Emergency Unit. Egyptian Nursing Journal. 2013; 4(1): 60-74.

[15]. Vincent , V. (2012). A study to assess the effectiveness of self-instructional module on knowledge and attitude of staff nurses regarding umbilical cord blood stem cells at selected hospitals in tumkur" Bharathi College Of Nursing, Published M. Sc. Nursing thesis submitted to Rajiv Gandhi University of Health Sciences Karnataka. 2012; 33.

[16]. Bombas, T., Costa, R., Palma. F., Vicente, L., Nogueira, A., and Andrade, S. (2012). Knowledge, attitude and practice survey among Portuguese gynaecologists regarding combined hormonal contraceptives methods. Eur J Contracept Reprod Health Care. 2012; 17(2): 128-134. PMid:22200109 http://dx.doi.org/10.3109/13625 187.2011.631622

[17]. Chen C. \& Lou M. (2013). The effectiveness and application of mentor ship programmes for recently registered nurses a systematic review. J Nurs Manag. 2013.

[18]. Varghese, S. (2013). Effectiveness of structured teaching program on stem cell therapy among fourth years nursing students at nursing college Mangalore. Published M. Sc. Nursing thesis submitted to RaJiv Gandhi University of health sciences Karnataka

[19]. Askarian, A., Memish, Z., and Khan, A. Knowledge, practice, and attitude among Iranian nurses, midwives, and students regarding standard isolation precautions. Infection Control and Hospital Epidemiology. 2007; 28(2): 123-127. PMid:17265414 http://dx.d oi.org/10.1086/510868 